7 Hammerschlag MR. Chlamydial Infections. In: Behrman RE, Kliegman RM, Jenson HB, eds. Nelson Textbook of Pediatrics. 17th Edn. Philadelphia, Saunders, 2003; pp. 994-999.

8 American Academy of Pediatrics Subcommittee on Diagnosis and Management of Bronchiolitis, Diagnosis and management of bronchiolitis. Pediatrics 2006; 118: 1774-1793.

9 Klassen TP, Rowe PC, Sutcliffe T, Ropp LJ, McDowell IW, Li MM. Randomized trial of salbutamol in acute bonchiolitis. J Pediatr 1991; 118: 807-811.
10 Schweich PJ, Hurt TL, Walkley EI, Mullen N, Archibald LF. The use of nebulized albuterol in wheezing infants. Pediatr Emerg Care 1992; 8: 184-188.

11 Schuh S, Canny G, Reisman JJ, et al. Nebulized albuterol in acute bronchiolitis. J Pediatr 1990; 117: 633-637.

12 Menon K, Sutcliffe T, Klassen TP. A randomized trial comparing the efficacy of epinephrine with salbutamol in the treatment of acute bronchiolitis. J Pediatr 1995; 126: 1004-1007.

\title{
Antibiotics in RSV bronchiolitis: still no evidence of effect
}

\section{To the Editors:}

Avoiding unjustified antibiotic use is of paramount importance in order to decrease worldwide development of resistance. In this context, the study by TAHAN et al. [1], which reports the results of a randomised, double-blind, placebo-controlled trial comparing clarithromycin $15 \mathrm{mg} \cdot \mathrm{kg}^{-1} \cdot \mathrm{day}^{-1}$ for 3 weeks with placebo in infants with respiratory syncytial virus (RSV) bronchiolitis, is disturbing. Careful analysis of the study shows important methodological flaws, making the results unreliable and the recommendations premature.

First, the trial has not been registered at www.controlledtrials.com, which is now a prerequisite for randomised controlled trials (RCTs) [2]. Secondly, and even more importantly, the RCT lacks a proper power analysis. In the design of an RCT it is necessary to know beforehand how large a sample is needed to enable statistical judgments that are accurate and reliable. The sample size seems to be too small to draw any evidence-based conclusions. Moreover, it is not known if patients with prior use of antibiotics were excluded from the analysis. Finally, why did TAHAN et al. [1] choose to use an antimicrobial drug that must be administered for 3 weeks, while the length of stay in the control group is only $88 \mathrm{~h}$ ?

Numerous studies have shown that the occurrence of a secondary or concurrent bacterial infection in hospitalised children with RSV lower respiratory tract disease (LRTD) is $<1 \%$ [3]. Despite this, nearly half of all hospitalised infants with RSV LRTD are treated with antibiotics [4-6]. This unjustified use of antibiotics must be avoided, because of the close link with the development of antimicrobial resistance [7]. Therefore, there is a rationale for a properly designed RCT equivalence trial studying antibiotics in hospitalised infants with RSV LRTD.

Unfortunately, studies such as the one by TAHAN et al. [1] do not provide a justified basis for the treatment of hospitalised infants with respiratory syncytial virus and do not help in a reduction of abuse of antibiotics.
M.C.J. Kneyber* and J.L.L. Kimpen ${ }^{\#}$

*Dept of Paediatric Intensive Care, VU University Medical Center, Amsterdam, and "Dept of Paediatrics, Wilhelmina Children's Hospital, Utrecht, The Netherlands.

\section{STATEMENT OF INTEREST}

None declared.

\section{REFERENCES}

1 Tahan F, Ozcan A, Koc N. Clarithromycin in the treatment of RSV bronchiolitis: a double-blind, randomised, placebocontrolled trial. Eur Respir J 2007; 29: 91-97.

2 Dickersin K, Rennie D. Registering clinical trials. JAMA 2003; 290: 516-523.

3 Bloomfield P, Dalton D, Karleka A, Kesson A, Duncan G, Isaacs D. Bacteraemia and antibiotic use in respiratory syncytial virus infections. Arch Dis Child 2004; 89: 363-367.

4 Behrendt CE, Decker MD, Burch DJ, Watson PH. International variation in the management of infants hospitalized with respiratory syncytial virus. International RSV Study Group. Eur J Pediatr 1998; 157: 215-220.

5 Brand PLP, Vaessen-Verberne AAPH Differences in management of bronchiolitis between hospitals in the Netherlands. Dutch Paediatric Respiratory Society. Eur J Pediatr 2000; 159: 343-347.

6 Vogel AM, Lennon DR, Harding JE, et al. Variations in bronchiolitis management between five New Zealand hospitals: can we do better? J Paediatr Child Health 2003; 39: 40-45.

7 Barlow G, Nathwani D. Is antibiotic resistance a problem? A practical guide for hospital clinicians. Postgrad Med J 2005; 81: 680-692. 